\title{
The Policy Approach In Promoting Small And Medium Sized Enterprises In Japan
}

Rika Nakagawa, Toyo University, Japan

\begin{abstract}
The purpose of this paper is threefold: 1) to investigate the role of small and medium sized enterprises (SMEs) in the economy, 2) to classify obstacles for SMEs' growth, and 3)to review policy measures in Japan and problems to be solved as soon as possible.

This study indicates that SMEs have played a significant role in the economy. SMEs create production linkages among companies in the economy by supplying goods and services. In addition, SMEs have been a main promoter of trade. Moreover, SMEs provide people with various job opportunities, which generate an important source of income. SMEs, however, face many obstacles to sustainable development. One major problem is that SMEs have limited financial resources compared with large enterprises. Due to this financial constraint, it is difficult for SMEs to upgrade production facilities and keep up with new technology. Furthermore, SMEs are suffering from a shortage of skilled labor. This becomes more serious when they try to expand business in the global market. In order for SMEs to compete with rivals in the international market, employees need a wide variety of knowledge and skills, such as foreign business knowhow, human resource management, foreign language expertise, etc. Human resources of SMEs are often insufficient to meet their business needs.

In Japan, both the central and local governments have implemented various policies to address these challenges. This research found that some policies worked well and supported SMEs, while others did not. The author, however, points out that some studies need to be carefully reconsidered because there is no consistent framework for policy evaluation. This means that the results of the evaluation of SMEs are likely to vary because of the different methodologies used. Thus, this paper recommends the government develop an appropriate system for assessing SME policies.
\end{abstract}

Keywords: Small and Medium Sized Enterprises (SMEs); Japan; SME Policy; Policy Evaluation

\section{INTRODUCTION}

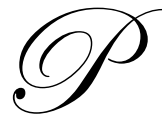

rivate companies are significant and key players in the economy. In any economy, large enterprises (LEs) tend to be regarded as the leading indicator of a country's economic vigor. Small and medium sized enterprises (SMEs), however, are also important for our economy and have a significant impact on such areas as employment, trade, etc.

When focusing on the size of a company, it is often said that SMEs face more challenges than LEs. In general, SMEs are too small to benefit from the economy of scale and this has a direct and negative effect on their productivity. In addition, it is difficult for SMEs to upgrade production facilities and keep up with new technology because SMEs have limited financial resources. Moreover, SMEs are suffering from a shortage of skilled labor. This becomes more serious when they try to expand business in the global market. In order for SMEs to compete with rivals in the international market, employees need a wide variety of knowledge and skills, such as foreign business know-how, human resource management, foreign language expertise, etc. Human resources of SMEs are often insufficient to meet their business needs. 
In economics, those problems that SMEs face are usually regarded as a market failure. It provides a reasonable reason for the government to assist SMEs in various ways. The government's policy for SMEs, however, has been criticized because an intervention by the government results in a distortion of the market mechanism. The other criticism is about a trade-off between the positive and negative effects of the policy. The government has diversified economic objectives to be achieved and these are sometimes mutually incompatible. An appropriate policy to achieve one objective does not always lead to a desirable outcome for another objective. Therefore, SME policies have to be considered from various viewpoints.

In this paper, the author will explore three areas: 1) difficulties that SMEs are facing, 2) government policies regarding SMEs, and 3) suggestions for improvements in government SME policies. This study focuses on the case of Japan and draws some lessons from the experience. The Japanese government has been keen to help SMEs because SMEs have played an important role in the economy. This study is expected to provide useful suggestions for other countries, particularly developing economies, where the government expects to SMEs become an engine of economic development.

The next section classifies the role of SMEs in the economy, followed by a section reviewing problems that are difficult for SMEs to deal with: 1) productivity, 2) information technology (IT), 3) globalization, and 4) competitiveness in the domestic/global markets. Then the next section outlines some of the government policies that are already in place to support SMEs in Japan, as well as pros and cons of the government programs. The final section consists of a summary and discussion of the future agenda for the Japanese government to improve policies regarding SMEs.

\section{THE ROLE OF SMES IN THE ECONOMY}

The phrase "small and medium sized enterprises" started to be commonly used in Japan after the Meiji era (1868-1912) (Sato 1989). In those days there was no definition of a SME and the idea was vague; it meant that the size of a company was "relatively" small in comparison with other companies. In 1963, the government enacted the Small and Medium-sized Enterprise Basic Act, and a definition of SME was legally determined.

As noted in Table 1, the definition was set by capital and labor in each sector. In the retail sector, total capital of SMEs should not exceed 50 million yen (approximately US\$620,000), or less than 50 employees. In the general service sector, total capital of SMEs should be less than 50 million yen or 100 employees. SMEs in the wholesale sector defined that capital should not exceed 100 million yen (approximately US $\$ 1.2$ million), or 100 employees. In the manufacturing, construction, transportation and other sectors, total capital of SMEs should be less than 300 million yen (approximately US\$3.7 million), or less than 300 employees. A micro company is defined as an entity that hires less than five employees in the commerce and services sector and less than 20 employees in the manufacturing and other sectors under the Act.

Table 1: Definition of SME in Japan

\begin{tabular}{|c|c|c|c|}
\hline Sector & Capital & & Employee \\
\hline Retail trade & Not exceed 50 million yen & & Not exceed 50 \\
\hline Service & Not exceed 50 million yen & & Not exceed 100 \\
\hline Wholesale trade & Not exceed 100 million yen & or & Not exceed 100 \\
\hline Manufacturing, Construction Transportation, others & Not exceed 300 million yen & & Not exceed 300 \\
\hline
\end{tabular}

(Source) Small and Medium-sized Enterprise Basic Act, Article 2

The role of SMEs in the economy varies in accordance with the economic situation. Small and Medium Enterprise Agency (1973) pointed out three outstanding roles of SMEs in the 1960s and early 1970s in Japan. First, under a favorable economic situation, small companies were expanding rapidly and many of them increased in size. Those companies were the main promoters of economic growth. Second, small subcontractors supported a massproduction system in manufacturing and heavy industry. Third, SMEs stimulated local economies in the country, in particular through the retail and distribution sectors. Those sectors were relatively small compared to other sectors, but the business activities of SMEs had been a contributing factor in the development of local industries. 
Small and Medium Enterprise Agency (1976) explained an important role of SME in trade. For example, in 1961 exports by SMEs accounted for 55.2\% of Japan's total exports. SMEs utilized domestic materials to process consumer goods and SMEs significantly contributed to the development of light industry. With regard to the balance of payment, SMEs also contributed to the accumulation of foreign reserves that were necessary for imports of goods/services and the repayment of the country's external liabilities.

According to Small and Medium-sized Enterprise Basic Act, the roles of SMEs are illustrated as promoters of new industries, employment opportunities, competition in the market, and regional economies (Article 3). The first role implies a business venture that takes risks to develop new industries. In Japan, the number of high-tech and IT business ventures has increased since the 1970s. One reason for this occurrence is that heavy industry in Japan matured and many of these companies avoid taking high risks for their business. Business ventures could open new windows to start new industries (Kiyonari 2009, pp. 272-273). The second role emphasizes on the job opportunities for workers. In general, total employment in SMEs is greater than that of LEs in the economy. In Japan, as of 2006, employees of SMEs made up $69 \%$ of the labor force, while LEs only accounted for $31 \%$. Asian Development Bank (2009) estimated employment in the manufacturing sector by size of companies in selected Asian economies and revealed that the majority belonged to SMEs in some economies: $89.5 \%$ in India, $77.1 \%$ in the Philippines, $71 \%$ in Indonesia, $70.4 \%$ in Korea, $58.4 \%$ in Thailand and $60.1 \%$ in Taipei, China. In Malaysia and The People's Republic of China, the share was less than 50\%, but it accounted for $47.2 \%$ and $48.1 \%$ respectively (Asian Development Bank 2009, p. 3). This has an important implication that SMEs have a significant impact on employment in the economy. In terms of the third role, SMEs encourage competition in the market because a large number of SMEs exist in the economy. As of 2006, SMEs' share in the Japanese economy was 99.7\%, an overwhelming majority. As for the last role pointed out by the SMEA, SMEs form industrial clusters in a certain region, such as local area, to become the driving force of local economic development. Those SMEs created employment opportunities in the area; people living there are able to earn income that generates an increase in consumption.

\section{WHAT KIND OF DIFFICULTIES HAVE SMES BEEN FACING?}

As has been noted in the first section, SMEs have played critical roles in the economy. It is often said that SMEs face difficulties or limitation, however. This section examines difficulties for SMEs related to productivity, information technology, globalization and competitiveness in domestic/global markets.

\section{Disadvantages of SMEs in Markets}

SMEs are suffering disadvantages in several markets as Kiyonari (2009) mentioned. When SMEs trade goods and services with LEs, SMEs sometimes have unfair or unacceptable terms of trade imposed on them by LEs in the market due to a difference of negotiating power. SMEs have to compete with their rivals whereas only one LE may be a buyer in a market, enjoying a monopsony and making SMEs' business severely difficult. Kiyonari (1997) pointed out that in a monopsony LEs have an advantage over SMEs in price negotiations, SMEs may have to accept an undesirable price. This situation is one of the toughest situations for SMEs to deal with.

In terms of the workforce, SMEs face difficulties in hiring well-qualified labor in spite of a labor shortage. People in Japan, especially the younger generation, tend to prefer to work for LEs because working conditions of SMEs are relatively worse than that of LEs. For instance, workers in SMEs have to accept lower wages despite long working hours. Furthermore, SMEs are fragile and affected more seriously by business fluctuations; in the worst scenario, SMEs are most at risk of going bankrupt. Labor is trying to find a better working environment and employee benefits, and therefore frequent job hopping is not a surprising issue. This adds to the difficulties SMEs have with the development and retention of a skilled workforce.

On the issue of access to capital for SMEs, banks are hesitant about providing loans to SMEs; most of them have to do business under tight financial constraint. A loan transaction always contains risks when the ability to repay a loan may depend on the borrower's business success or failure. Therefore banks always request collateral in order to reduce such risks. Assets, such as land, real estate and capital equipment are popular as collateral; however, SMEs usually have a shortage of collateral to obtain enough loans from banks. In addition, as has been noted, SMEs 
are easily affected by changes in business or the economic situation. Although SMEs play the role of a shock absorber in the economy and protect LEs by spreading the impact of an economic downturn across many SMEs, SME lending contains the highest risk from a viewpoint of banks. Another reason banks are not willing to supply loans to SMEs is that the principal amount of loan for SMEs is too small for the bank to be able to achieve the economy of scale in lending. As a result, SMEs are generally not able to obtain enough financing to upgrade their production equipment and introduce advanced IT systems.

\section{Globalization and SMEs}

As economic globalization has proceeded quickly, private companies have been forced to consider doing business with foreign players. Tambunnan (2007) discussed impacts of economic globalization on SMEs. Tradeoriented SMEs have to compete with foreign companies not only on price but on quality of goods and services; small manufacturers cannot succeed in the face of cheap foreign imports. For domestic-oriented SMEs, it is often difficult to purchase raw materials in the domestic market if those materials are exported to foreign countries. The domestic market for raw materials excess demand, therefore the price rises. Domestic small companies have to resign themselves to making less profit on sales due to a rise in production costs. Thus, globalization has a larger impact on SMEs than on LEs.

In Japan, many SMEs followed LEs to foreign countries, in particular Asian economies. The motivation for this is to maintain business relationships with their clients, to reduce business costs, to gain access to cheap labor, to explore new markets, etc. When SMEs decide to do business abroad, the most serious problem is a lack of human resources. In foreign business, both employees and employer should be fully acquainted with the social, economic and political situation in foreign countries. Before they start foreign business, the company usually does a pilot survey to determine whether the business is feasible or not by collecting information about the culture, religion, business ethics, the legal system, of the foreign countries where they plan to do business. The biggest question here is how to collect the information provided in a foreign language. There are only a few employees in SMEs who may be familiar with local languages. In this situation, it is especially difficult for SMEs to understand foreign countries and recognize risks of foreign business. Even after they start doing business, the CEO of the company has to hire local staff and to at least be able to communicate with them in English. A shortage of well-qualified human resources in SMEs is certainly a bottleneck when it comes to dealing with the inescapable challenges of globalization.

\section{Information Technology and SMEs}

The development of IT has a great impact on business in the world. Tsuchiya (1989) describes many areas in which the role of IT is becoming more important in business: research and development, inventory control, supply management of goods and services, customer relations, so on. As the lifecycle of goods has shortened, companies have to understand market needs as quickly as possible in order to respond to the changes in market trends. IT makes such a quick response possible by immediately sending market data or information from one place to another.

In terms of productivity, IT makes it possible to streamline business procedures and pursue speedy outcomes to achieve increased productivity. It is often observed that productivity of SMEs is relatively lower than that of LEs, Small and Medium Enterprise Agency (1970) argued lower productivity of SMEs resulted from an insufficient capital-labor ratio. The capital-labor ratio consists of two factors; an investment in tangible fixed asset, such as production equipment, and workforce. As pointed out in the last section, SMEs cannot employ enough qualified workers; the only way to improve their productivity is to increase investments in fixed assets. Investments in IT or IT-related equipment are essential to pursue better productivity. This, however, is not easy for SMEs because of the financial restraint as explained. In addition, fewer IT experts work for SMEs. These factors make it almost impossible for SMEs to introduce new IT or upgrade their IT systems. 


\section{GOVERNMENT POLICY TO SUPPORT SME}

\section{Why does Government Assist SMEs? Pros and Cons}

The previous sections discussed the business operations and market challenges facing SMEs. They may be characterized as market failures caused from information asymmetry, public goods, externality, and monopoly. If these are observed in a particular market, the market mechanism fails to allocate resources efficiently in the market. Thus government intervention in the market is fully justified and the government implements some public policies to adjust the misallocation of goods and services. Issues discussed in this paper arise from a problem of information asymmetry; it is natural that SMEs call for government intervention to support their business. Castillo, et. al. (2010) agrees that policy assistance for SMEs is needed to find a solution to difficulties in the financial market, in particular. The study is positive about the government policies on SMEs that encourage them to be more competitive. The role of the government is important in the labor market as well to increase employment. Asian Development Bank (2009) put an emphasis on SMEs as engines for job-creation, and the government should create opportunities to match potential labor with SMEs. These government interventions should be implemented to remove obstacles to SMEs' business. The noteworthy point of these arguments is that SMEs are not regarded as weak; the government should not be overprotective of SMEs. The government should deregulate particular rules so that SMEs have the ability to compete with rivals and LEs in the market.

On the other hand, Castillo, et. al. (2010) introduced arguments against government policies to assist SMEs from the perspective of efficiency, employment and subsidy. First, LEs in a particular industry that achieve economies of scale are more effective and efficient, therefore such companies have greater possibilities to generate more employment; SMEs' role in job creation should not be overvalued. Second, a subsidy, the typical public policy to support SMEs, has a harmful influence on the economy. The issue of subsidies to support SMEs has triggered much debate among economists; most of them have negative views on it. One major claim is that a subsidy causes a distortion of the market mechanism. The other is that a subsidy is discriminatory and unfair against LEs. These views conclude that the government should not implement particular policies on SMEs. Furthermore, many economists fear that government may not have the ability to correctly choose the appropriate SMEs to assist. The failure of the government to correctly choose which SMEs should be supported and which ones to allow to go bankrupt may have a more seriously negative and long-term economic impact; therefore a subsidy on SMEs is not acceptable.

Audretsch (2002) and Beck et al. (2005) noted that SMEs definitely create job opportunities; however, SMEs trigger more unemployment because of their low survival rate. New business always starts on a small scale and gradually grows in size and scope. They are crucial in creating employment and their impact is positive and indispensable. Small businesses, however, are fragile and a large number of small companies fail. When this happens, employees become jobless. Comparing the total number of people employed by SMEs to the number of people who have lost their jobs due to the failure of SMEs in a certain period, it may show a clear picture of the negative impact that jobless due to SME failure has on the economy. Asian Development Bank (2009) supported the viewpoints of Audretsch (2002) and Beck et al. (2005) from evidence of the case of Korea and the Philippines. The study analyzed whether SMEs provided job opportunities to labor in Korea and the Philippines from the end of the 1990s to the mid-2000s. The research found that in Korea SMEs played a vital role to create job opportunities in the labor market, whereas there was no convincing evidence in the Philippines. From this result, SMEs are not always enhancing employment in the economy.

Miwa (2001) shed light on an ineffectiveness of fund-support policies to SMEs in Japan. This research revealed that SME finance by the government had a negligible influence on investment in plant or production equipment of SMEs. The author concluded that SME finance was not effective in Japan in the surveyed period. The government lending through a government-linked financial institution was expected to substitute for private lending, however, the findings imply that policy-based finance to SMEs may not show remarkably positive results.

Although there is no consensus about the effects of government policies aimed at supporting SMEs, governments in many countries have implemented several programs for SMEs. The government needs to show evidence that SME-oriented programs are effective and efficient because the source of finance of SME programs is 
from taxpayers. The government should have accountability to taxpayers; they should improve the programs to persuade taxpayers of their benefits. The government needs to carefully evaluate the results of its SME policy.

\section{SME POLICIES IN JAPAN}

\section{Institutions Providing SME Support}

Small and Medium Enterprises Agency

The Japanese government has implemented various policies in order to promote SMEs in the country. Small and Medium Enterprise Agency (SMEA) established under Act for Establishment of the Small and Mediumsized Enterprise Agency in 1948 is the major organization that has been responsible for SME support programs. According to Kiyonari (2009), the SMEA was modeled on the Reconstruction Finance Corporation (RFC) in the U.S. The RFC was established for write-offs of non-performing loans of banks after the great depression triggered by the market crash in 1929, but another important role was to provide loans for SMEs. The U.S. government highly valued SMEs that contributed to the munitions industry during the Second World War; the U.S. government put emphasis on the function of SMEs in the economy even after the War. Therefore the government had high expectations about the role of the RFC, which became a core institution for SME support in the country (Kiyonari 2009, p.2).

The SMEA has been organizing programs for SMEs into four categories: management support, financial support, fiscal support, and commerce and regional support as shown in Table 2. Some programs contained multiple objectives. Among them, the most popular programs in 2010 were consulting services on business globalization and the development of new markets, and protection of intellectual property (Small and Medium Enterprise Agency $(2010))^{1}$. This implies that SMEs have less relevant information for smooth business operation, thus consulting services are vital for SMEs.

Table 2: Outlines of Major SME policies by the SMEA

\begin{tabular}{cl}
\hline Management Support & Assists those planning to start a business or venture owners trying to improve their operations \\
financial and obtaining relevant information.
\end{tabular}

\footnotetext{
${ }^{1}$ In 2011, reconstructing SME business and supply chain among SMEs in Tohoku area, where an unprecedented earthquake and tsunami hit in March 11, was the other targeted project. 


\begin{tabular}{|c|c|}
\hline \multicolumn{2}{|r|}{ Table 2 (continued) } \\
\hline Small and medium & Supports R\&D and human resources development at SMEs with key manufacturing \\
\hline Manufacturers & Selects 300 of Japanese Exciting Monozukuri (Manufacturing) SMEs. \\
\hline $\begin{array}{l}\text { Technological IT and } \\
\text { innovation, energy }\end{array}$ & $\begin{array}{l}\text { Assists SMEs committed to technological development, IT utilization and higher energy } \\
\text { providing subsidies, financial assistance and relevant information. }\end{array}$ \\
\hline Intellectual property & $\begin{array}{l}\text { Supports SMEs' intellectual property strategies by implementing measures to protect } \\
\text { property and measures to combat damage caused by counterfeiting. }\end{array}$ \\
\hline SME Assistance Centers & $\begin{array}{l}\text { Dispatches experts to assist SMEs in addressing difficult or specialized business challenges } \\
\text { of new operations, business succession) and otherwise helps SMEs directly or via support }\end{array}$ \\
\hline \multicolumn{2}{|l|}{ Financing support } \\
\hline $\begin{array}{l}\text { Safety-net guarantee } \\
\text { Program }\end{array}$ & $\begin{array}{l}\text { Supports SMEs whose business stability is threatened by external facers (e.g., a major } \\
\text { restricted operations or application for rehabilitation procedures, the impact of a disaster, } \\
\text { main bank) by making additional credit guarantees available. }\end{array}$ \\
\hline Safety-net loans & $\begin{array}{l}\text { Makes loans to SMEs temporarily facing cash-flow problems due to a radical change in the } \\
\text { environment, the bankruptcy of a major customer, or the streamlining of the main bank. }\end{array}$ \\
\hline \multicolumn{2}{|l|}{ Fiscal Support } \\
\hline Taxation & Gives information and advice on various tax measures to support SMEs. \\
\hline Accounting & $\begin{array}{l}\text { Gives information and advice on SME accounting, which helps SMEs to enhance their } \\
\text { analyze management, ensure financing and increase order intake. }\end{array}$ \\
\hline Companies Act & $\begin{array}{l}\text { Gives information and advice on the new Companies Act, which additionally includes systems } \\
\text { bring significant benefits to SMEs such as the accounting adviser system. }\end{array}$ \\
\hline Business succession & Gives information and advice on measures to support SMEs' smooth business succession. \\
\hline \multicolumn{2}{|c|}{ Commerce and Regional Support } \\
\hline Revitalization of commerce & $\begin{array}{l}\text { Supports efforts to improve the attractiveness of small and medium merchants, shopping } \\
\text { city centers. }\end{array}$ \\
\hline Regional industries & $\begin{array}{l}\text { Invigorates regional industries, such as locally based industries and traditional hand crafts } \\
\text { providing subsidies and low-interest loans. }\end{array}$ \\
\hline $\begin{array}{l}\text { Collaboration between } \\
\text { agriculture, commerce and } \\
\text { Industry }\end{array}$ & $\begin{array}{l}\text { Comprehensively assists business activities conducted by organic partnerships between SMEs } \\
\text { those engaged in agriculture/forestry/fisheries through the effective use of their business }\end{array}$ \\
\hline $\begin{array}{l}\text { "Meet and Experience } \\
\text { Regional Attractiveness" } \\
\text { Campaign }\end{array}$ & Aggressively increases the publicity of attractive regional products. \\
\hline
\end{tabular}

(Source) Small and Medium Enterprise Agency's web site (www.chusho.meti.go.jp/sme_english_outline_04/01_06.html, last cited on February 29, 2012)

\section{Other Institutions of SME Support}

The Ministry of Economy, Trade and Industry founded nine regional branches - Hokkaido, Tohoku, Kanto, Chubu, Kinki, Chugoku, Shikoku, Kyushu and Okinawa - and SME policies by the central government are implemented through these regional offices. Local governments set up a particular department or unit that deals with needs of SMEs as well. Government agencies are playing an important role for smooth business of SMEs. The Organization for Small \& Medium Enterprises and Regional Innovation, Japan (SMRJ)2 ${ }^{2}$, started their services in

\footnotetext{
${ }^{2}$ The Japanese government merged three agencies under Ministry of Economy, Trade and Industry that supplied similar services
} into one, named Organization for Small \& Medium Enterprises and Regional Innovation. 
2004 with a network comprised of one main office, nine regional branches, and the Institute for Small Business

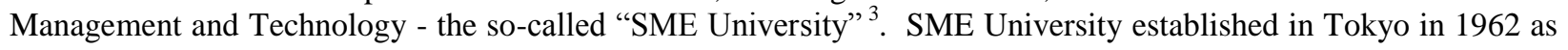
a research institution. Since 1980, the Japanese government has founded SME University in nine regions to support local SMEs; they offer training programs for human resources of SMEs.

SMEs are able to utilize services provided by local government or industrial associations as well (Table 3 ). Japan consists of 47 administrative divisions and local governments of those divisions have SME support centers. For instance, Tokyo Metropolitan Small and Medium Enterprise Support Center (Tokyo-kosha) was established in 1966. Fifteen major supports have been prepared for SMEs (Table 4). Surprisingly, it is obvious that the SMEA and Tokyo-kosha are supplying very similar programs, many of them duplicated (Table 2 and 4), for example, a consulting service on intellectual property. The SMEA supports strategies to protect intellectual property rights and advises how to reduce losses if such rights are abused. The Tokyo-kosha program provides relevant information on intellectual property rights, advice on rights protecting patents, trademarks, copyrights, etc. The guidance on how to secure intellectual property rights by the public sector is helpful if SMEs don't employ an expert on the right. Such government service is a good incentive for SMEs to pursue "only-one" technology or knowledge. Both web sites, however, show similar explanations. Therefore, SMEs may not know which to visit first, either the central or the local government.

On the other hand, some other programs by the Tokyo metropolitan government are unique. The student entrepreneur championship is a competition of business plans explored by students and decides a winner and they assist the winner in carrying out the business plan. This program strongly believes that young entrepreneurs entering new markets are vital to the success of the economy (Tokyo-kosha's web site) ${ }^{4}$.

Table 3: Institutions Providing SME Support

\begin{tabular}{|c|c|}
\hline Institution & URL ([J]: Japanese only, [E]: English available ) \\
\hline Area Bureau of Ministry of Economy, Trade and Industry & [J] http://www.chusho.meti.go.jp/link/keizaikyoku.html \\
\hline Local governments & [J] http://www.chusho.meti.go.jp/soudan/ken_tantouka.html \\
\hline Organization for Small \& Medium Enterprises and Regional & [E] http://www.smrj.go.jp/english/index.html \\
\hline \multicolumn{2}{|l|}{ Innovation, Japan } \\
\hline SME support center of local governments & [J] http://www.chusho.meti.go.jp/soudan/todou_sien.html \\
\hline The Japan Chamber of Commerce and Industry & [E] http://www.jcci.or.jp/english/ \\
\hline List of local offices & {$[\mathrm{J}]$ http://www.cin.or.jp/cin-cgi/me_list99open.asp } \\
\hline Central Federation of Societies of Commerce and Industry & [J] http://www.shokokai.or.jp \\
\hline List of 47 local society & [J]http://www.chusho.meti.go.jp/soudan/ken_shokokai.html \\
\hline National Federation of Small Business Associations & [E] http://www.chuokai.or.jp/en/index.htm \\
\hline List of local federation & [J] http://www.chusho.meti.go.jp/soudan/ken_dantyu.html \\
\hline National Federation of Shopping Center Promotion & {$[\mathrm{J}] \underline{\mathrm{http}: / / \mathrm{www} . \text { syoutengai.or.jp/ }}$} \\
\hline \multicolumn{2}{|l|}{ Associations } \\
\hline List of local associations & [J] http://www.syoutengai.or.jp/kenshinren/index.html \\
\hline National Federation of Credit Guarantee Corporations & {$[\mathrm{J}] *$ http://www.zenshinhoren.or.jp } \\
\hline Japan Finance Corporation & [E] http://www.jfc.go.jp/english/index.html \\
\hline The Okinawa Development Finance Corporation & [E] http://www.okinawakouko.go.jp/english/ \\
\hline Shoko Chukin Bank & [E] http://www.shokochukin.co.jp/english/index.html \\
\hline
\end{tabular}

\footnotetext{
${ }^{3}$ According to SMRJ, although the Institution is called "SME University", it doesn't give degrees of higher education after trainees finish a course. The SMRJ explains "the term 'SME University' is used to mean 'a high-level institute' where SMEs obtain practical skills useful in actual business operation." (Organization for Small \& Medium Enterprises and Regional Innovation, Japan, unknown published year, p. 1)

${ }^{4}$ www.tokyo-kosha.or.jp/english/files/22guide.pdf, last cited on March 4, 2012. 


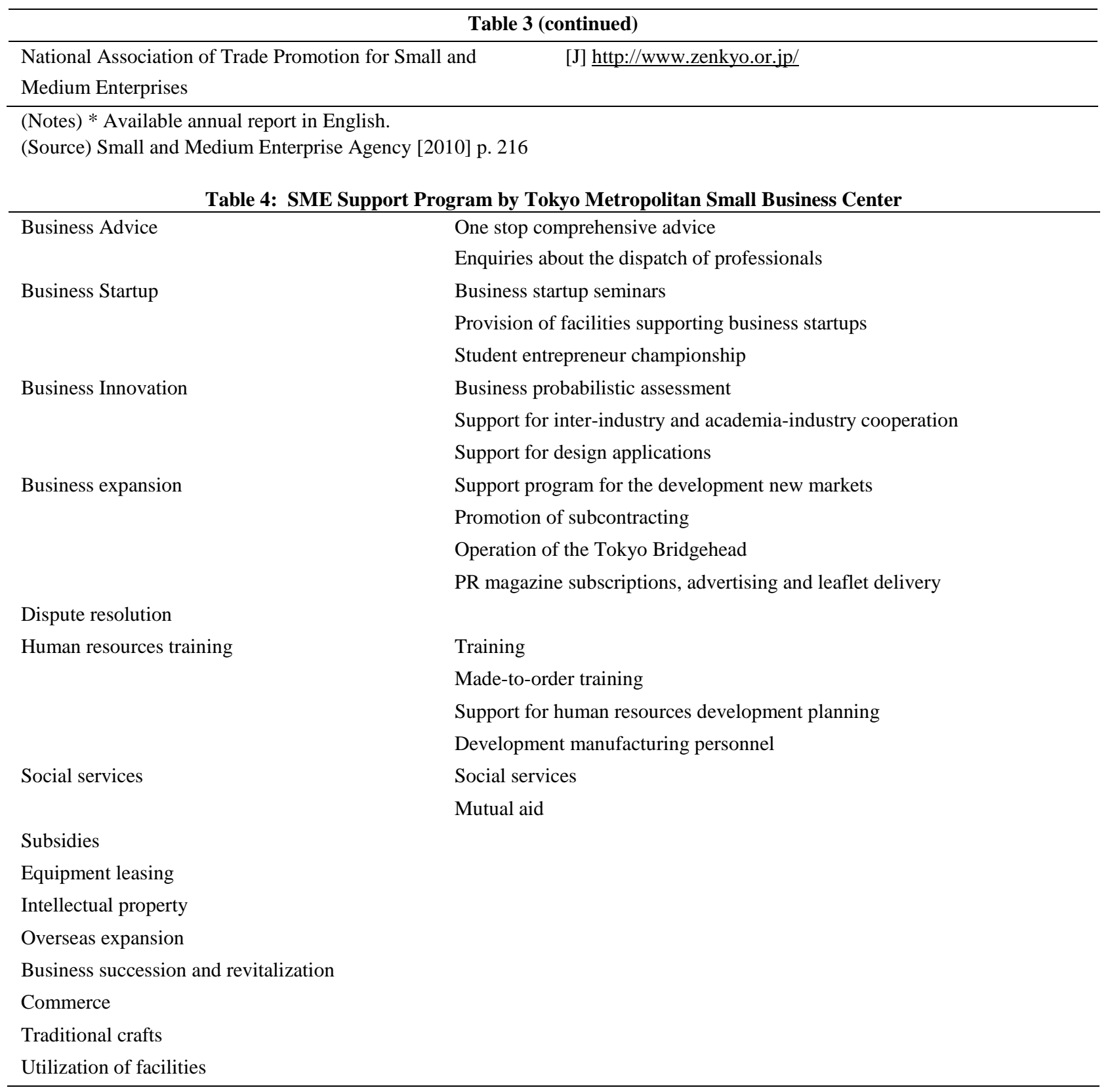

(Source) Tokyo Metropolitan Small and Medium Enterprise Support Center web site (www.tokyo-kosha.or.jp/english/index.html, cited on March 2, 2012).

\section{WHAT IS NEEDED TO IMPROVE EFFECTIVENESS AND EFFICIENCY OF THE GOVERNMENT PROGRAMS?}

The government implements policies by utilizing tax collected from the nation; therefore, the policies should have a positive impact on the entire country. In order to improve effectiveness and efficiency of the government policies, this paper suggests the government must take action to streamline programs and develop a policy evaluation system.

This paper examined SME programs by Japan's national government and local governments, using Tokyo as an example. As has been noted, the Tokyo metropolitan government prepares their own SME support programs; 
however, many programs are extremely similar. In some cases, the local government matches needs of SMEs with programs of the Japanese government and may just introduce them to SMEs. This case doesn't seem to be problematic; however, it is apparently inefficient if both the central and local governments are providing duplicated functions. The author has mentioned that SMEs may be confused about whether the central or local government should be visited first and which one to consult with. The governments are recommended to clearly divide their roles and simplify all programs for user-friendly services. This will lead to the perception of government accountability to taxpayers.

Within the central government, SME policies are not centralized and the programs are administrated by a number of different ministries. The main organization promoting SME policies in Japan is the SMEA under the Ministry of Economy, Trade and Industry. The SMEA provides financial support for SMEs; however, the Ministry of Finance is also engaged in lending activities. It is desirable that the government set up one institution that deals with all SME issues.

In addition, a policy evaluation system needs to be developed to improve SME policies of the government. The Japanese government began the policy evaluation system in some areas; however, an inherent weakness in the policy evaluation system is that it is difficult to accurately gauge the results of SME policy. The main reason is that it is impossible to compare before and after the policy. If productivity of an SME is improved after the policy, it is too hard to judge that better productivity resulted exactly from the policy. It is hard to remove other factors affecting the SME's productivity. When the direct impact of the policy on an SME's performance is inconsistent with an indirect impact, it is far more difficult to evaluate the policy. Suppose that an SME is willing to reduce production costs, then the SME decided to reduce labor costs as a result of advice by the government. The SME could achieve their objective by sacrificing many employees, causing hardship for them and members of their families. This may increase the unemployment rate in the country. In policy evaluation, the evaluator must carefully observe negative effects and evaluate both sides of the policy.

\section{CLOSING REMARKS AND FUTURE RESEARCH}

This paper reviewed the role of SMEs in Japan and the difficulties for them to continue their business. In the historical perspective, the phrase "small and medium sized enterprises" became common after the Meiji era. In those days, there were no legal grounds for dividing SMEs and LEs. SMEs were determined subjectively whether the size of a company was relatively small or big compared to other companies. In 1963, the Japanese government enacted the Small and Medium-sized Enterprise Basic Act and defined SMEs by sector.

The SMEA analyzed the role of SMEs in the Japanese economy and mentioned outstanding roles. In 1960s and 1970s, SMEs were a driving force of the rapid economic growth in Japan and became a base for the massproduction system in the manufacturing and heavy industries. SMEs made a great contribution to the economy through the retail and distribution sectors as well. Furthermore, trade by SMEs improved balance of payment of the country and it helped the government repay foreign debt and increase imports. SMEs were recognized as promoters of new industries, employment opportunities, competition in the market and regional economies.

Past literature admitted that SMEs were essential for economic growth; however, they often struggled with difficulties or barriers in markets. This paper pointed out several disadvantages that arose from market failures, the size of companies, shortage of labor and knowledge, etc. These disadvantages were rational reasons for the government to support SMEs by various policies, although a great deal of many research expressed negative opinions on SME policies. In the case of Japan, both the central and local governments implemented many policies. The Japanese government has provided programs on management, financial, fiscal and commerce and regional support. Local governments provide unique programs, but many of their programs are very similar to those of the central government. This system is not user-friendly because it is difficult for SMEs to find the most appropriate support for them. From a viewpoint of accountability to taxpayers, the central and local governments need to streamline the programs; the most desirable solution is to establish one organization dealing with all SME issues.

In addition to this problem, this paper highlights the importance of policy evaluation. The government needs to observe results of their policy very carefully and evaluate them. There are some obstacles to analyzing 
policy results accurately, however. One major obstacle is that it is almost impossible to specify a direct impact of a particular policy on an SME's performance. Policy evaluation contains such difficulties but the government should evaluate policy impacts, otherwise the government cannot achieve policy effectiveness and improve their programs. There is a question of how to investigate an SME's performance exactly resulted from a government policy. In some countries, policy evaluation on SME support programs has been conducted. It is useful to investigate the methodology and analyze its advantages and disadvantages. In order to understand the policy evaluation system better, further study is needed.

\section{AUTHOR INFORMATION}

Dr. Rika Nakagawa is an associate professor at the Faculty of Economics, Toyo University, Tokyo Japan. She teaches Asian Economy both in Japanese and English at the University. She earned her M.A. and Ph.D. in International Development from Nagoya University. She has conducted research on economic development of Southeast Asia, mainly Malaysia. She is the author of The Asian Crisis and Monetary Policy in Malaysia (in Japanese) and has published extensively and given presentations at various conferences, both in Japan and internationally, on the issues of economic development. Her current interest is SMEs and their role for economic development. E-mail: rika@toyo.jp

\section{REFERENCES}

1. Asian Development Bank, "Enterprises in Asia: Fostering Dynamism in SMEs," Special Chapter of Key Indicators for Asia and the Pacific 2009, Manila: Asian Development Bank, 2009

2. $\quad$ Audretsch, David B., "The Dynamic Role of Small Firms: Evidence from the U.S.," Small Business Economics, Vol. 18, No. 1-3, pp. 13-40, 2002.

3. Beck, Thorsten, Asli Demirguc-Kunt, Luc Laeven, and Ross Levine, "Finance, Firm Size and Growth," Journal of Money, Credit and Banking, Vol. 40, No. 7, pp. 1379-1405, 2008.

4. Castillo, Victoria, Alessandro Maffioli, Ana P. Monsalvo, Sofia Rojo, and Rodolfo Stucchi, "Can SME Policies Improve Firm Performance? Evidence from an Impact Evaluation in Argentina," Working Paper OVE/QP-07/10, Inter-American Development Bank, 2010 (http://www.iadb.org/ove/Documents/uploads/cache/35545433.pdf, downloaded on February 25, 2012).

5. Kiyonari, Tadao, A Textbook of Small and Medium Sized Enterprises (in Japanese, Chu-sho Kigyo Dokuhon), Tokyo: Toyo Keizai, 1997.

6. Kiyonari, Tadao, The History of SMEs Policies in Japan (in Japanese, Nihon Chu-sho Kigyou Seisaku Shi), Yuhikaku, 2009.

7. Miwa, Yoshiro, “Japanese Economic Policy and Policy Evaluation: The Case of 'Industrial Policy'," (in Japanese, Nihon no Keizai Seisaku to Seisaku Kenkyu, Toriwake Seisaku Hyoka ni Tsuite: Sangyo Seisaku no kesu), Economic Review (in Japanese, Keizai Kenkyu), Vol. 52, No. 3, pp. 193-204, 2001.

8. Organization for Small \& Medium Enterprises and Regional Innovation, Japan, "Guide to Tokyo SME University," downloaded from SMRJ web site (http://www.smrj.go.jp/inst/tokyo/form/englishguide/index.html, last cited on March 2, 2012)

9. Sato, Yoshio, "Changes of SMEs in the Japanese History" (in Japanese, Rekishi no Naka de Henbo Suru Chu-sho Kigyo: Mondai to Kenkyu no Rekishi), Moriaki Tsuchiya and Yoshiro Miwa (eds.) Small and Medium Enterprises in Japan (in Japanese, Nihon no Chu-sho Kigyo), Tokyo: University of Tokyo Press, pp. 3-23, 1989.

10. Small and Medium Enterprise Agency, 1973 White Paper on Small and Medium Enterprises in Japan (in Japanese), Tokyo: Small and Medium Enterprise Agency, 1973.

11. Small and Medium Enterprise Agency, 1976 White Paper on Small and Medium Enterprises in Japan (in Japanese), Tokyo: Small and Medium Enterprise Agency, 1976.

12. Small and Medium Enterprise Agency, "Guidebook to SME Program in 2011," download from SMEA web site (http://www.chusho.meti.go.jp/pamflet/g book/h22/pdf/index.html, last cited on February 29, 2012).

13. Tambunnan, Tulus, "Trade and Investment Liberalization Effects on SME Development: A Literature Review and Case Study of Indonesia," ESCAP, Towards Coherent Policy Frameworks: Understanding Trade and Investment Linkages, pp. 111-160, 2007 (http://www.unescap.org/tid/artnet/pub/tipub2469.asp, downloaded on February 25, 2012) 
14. Tsuchiya, Moriaki, "Information Technology and SMEs" (in Japanese, "Joho-ka to Chu-sho Kigyo"),

Moriaki Tsuchiya and Yosiro Miwa (eds.) Small and Medium Enterprises in Japan (in Japanese, Nihon no Chu-sho Kigyo), Tokyo: University of Tokyo Press, pp. 99-113, 1989.

Act: $\quad$ Small and Medium-sized Enterprise Basic Act, 1999 